\title{
Sosyal Medyada Kendini Açma: Öz Saygı, Güven ve Algılanan Faydanın Etkinliği Üzerine Bir İnceleme
}

\author{
DOI: 10.26466/opus.669190
}

$*$

\author{
Şükrü Balc1 ${ }^{*}$ Ayşe Arsal Gölcü ** \\ * Prof. Dr., Selçuk Üniversitesi/ İletişim Fakültesi, Konya/ TÜRKIYE \\ E-Posta: sukrubalci@selcuk.edu.tr \\ ORCID: 0000-0002-0477-0622 \\ ** Doktora Öğrencisi, Selçuk Üniversitesi/ Sosyal Bilimler Enstitüsü, Konya/TÜRKİYE \\ E-Posta: ayseegolcu@gmail.com \\ ORCID: 0000-0002-5724-6752
}

\section{Öz}

İletişim teknolojilerinin hızl gelişmesi ve yayg̨nlaşması; insanlara, kendilerini çevrimiçi olarak daha fazla anlatma noktasında çeşitli açılımlar sağlamaktadır. Sosyal medya aracılığıyla kullanıcılar kendi benliklerini, inançlarını, tutumlarmı, değerlerini ve kişisel hikâyelerini istediği gibi sunabilmektedir. $B u$ araçlar üzerinden yürütülen iletişimde sözsüz ipuçlarının etkisizliği, kullanıcıların kendilerini daha rahat açmalarına (ifade etmelerine) yardımcı olabilmektedir. Sosyal ă̆larda kendini açma, ayn zamanda özellikle gençler arasında kalıcı ilişkiler kurmanın bir yolu olarak da değgerlendirilebilir. İşte bu araştırmada, üniversite öğrencilerinin sosyal medyada kendini açma düzeyinin, algzlanan faydalar, özsaygı, sosyal medya kullanıcısına güven ve kullanım süresi arasındaki ilişki incelenmektedir. Saha araştırması yönteminin kullanıldığı araştırmada veriler, 395 kullanıcıdan yüz yüze anket tekniğìle toplanmıştır. Araştırma sonucunda kadınların sosyal medyada kendini açma düzeylerinin erkeklere nazaran daha yüksek olduğu dikkat çekmektedir. Araştırmada öz saygı ile ilişkiyi sürdürme ve yeni ilişki kurma gibi algılanan fayda boyutlarının, kendini açma puanın pozitif yönde anlamlı biçimde yordadığı belirlenmiştir. Kendini açma düzeyi ile sosyal medya kullanıcısına güven ve kullanım süresi arasında anlaml ilişki tespit edilememiştir.

Anahtar Kelimeler: Sosyal Medya, Kendini Açma, Özsayğ, Algılanan Fayda, Güven, İlişki 


\title{
Self-Disclosure on Social Media: Study on the Effect of Self-Esteem, Trust, and the Perceived Benefits
}

\begin{abstract}
Rapid development and diffusion of communication technologies; it provides various expansions to people to explain themselves online. Through social media, users can present themselves, beliefs, attitudes, values and personal stories as they wish. The ineffectiveness of nonverbal clues in communication through social media can help users to express themselves more easily. Self-disclosure in social media can also be considered as a way of establishing lasting relationships among young people. In this study, the relationship between university students' level of self-disclosure in social media, perceived benefits, self-esteem, trust in social media users and the duration of social media usage are examined. Data were collected from 395 users using face-to-face questionnaire technique. As a result of the research, it is noteworthy that women have higher levels of self-disclosure in social media than men. In the research, it was determined that perceived benefit dimensions such as maintaining relationship with self-esteem and establishing new relationship positively predicted self-disclosure score in social media. No significant relationship was found between the level of self-disclosure in social media and confidence in social media users and the duration of social media usage.
\end{abstract}

Keywords: Social Media, Self-Disclosure, Self-Esteem, Perceived Benefits, Trust, Relationship. 


\section{Giriş}

Toplumsal ve teknolojik ihtiyaçlara paralel olarak kendini geliştiren internet teknolojisi gündelik hayat pratiklerini sanal ortamlara taşıyarak bireylere yeniliklerle dolu sanal bir dünya simülasyonu sunmaktadır. Sosyal ağlarla çevrili bu yeni dünya bireyleri edilgenlikten kurtararak onlara sosyal yaşamda daha aktif bir rol vermektedir. Diğer bir deyişle internet sunduğu etkileşim, kitlesizleştirme ve eş zamanlı olamama gibi olanakları sayesinde kullanıcılar arasında daha önce hiç olmadığı kadar enformasyon akışı sağlamaktadır. Dolayısıyla bireyleri gerçeğe yakın bir sanal dünyaya çeken yeni medyanın farkı, alıcı ile kaynak arasında veri akışı sağlama hızı ve ulaşılan kitlenin geniş olmasından kaynaklanmaktadır (Başer, 2010, s.43). Bu bağlamda değerlendirildiğinde sosyal medya, dünya genelinde kişisel ağlar1 ve kurumsal bilgisayar sistemlerini birbirine bağlayan elektronik etkileşim ağı olarak tanımlanan internetin gelişmesiyle bireylere farklı bir sosyalleşme ve bilgilenme ortamı sunan web tabanlı hizmetler olarak tanımlamak mümkündür (Kuşay, 2010, s.67).

Günümüzde sosyal etkileşimin yüz yüze iletişimden web tabanlı ağlarla iletişime kaydığı bilinmekte ve ayrıca bu ağların yeni arkadaşlıklar edinmenin yanı sıra var olan arkadaşlıkları devam ettirmede de kullanıldığı görülmektedir. Her geçen gün farklı bir özellik ile kullanıcılara sunulan yeni sosyal ağlar bireylere sunmuş olduğu görsel tanitım, paylaşım ve beğeni olanakları ile kullanıcısını her geçen gün artırmaktadır (Toprak vd., 2009, s.29). Bireyler sosyal medyada oluşturdukları yeni kimlikleriyle yeni bir benlik sunumu gerçekleştirdikleri bu ortamlarda, gerçek hayatta olduklarından farklı davranışlar sergileyebilmektedir. Bu çerçevede, çalışmada ele alınan kendini açma davranışına bakıldığında, kendini açma (ifade etme) davranışı sözel bir faaliyet çerçevesinde kişinin kendini ve benliğini anlatmanın yanında, aynı zamanda yeni kimlik sunum mekânları olarak sanal ortamların ortaya çıkmasıyla, görsellik üzerinden kendini ifade etmeye ağırlık kazanmaya başlamıştır. Sosyal medya tarafından tetiklenen davranışlardan olan kendini açma, beğenme ve diğerleriyle kıyaslama gibi dürtüler bireylerin sosyal ağlarda farklı kimliklerle ortaya çıkmasına neden olmaktadır. Yapısı gereği kişisel sunum ve görsel market olarak değerlendirilebilen sosyal ağlar bireylerin benlik sunumları yanında kendilerini diğer kullanıcılarla pozi- 
tif ya da negatif olarak kıyasladığı alanlar olarak karşımıza çıkmaktadır (Jan, Soomro ve Ahmad, 2017, s.332).

Son yillarda yaşanan teknolojik sıçrama ve toplumsal olarak bu teknolojik sıçramaya entegre olma oldukça hızlı bir şekilde gerçekleşmektedir. Dolayısıyla insanların düşünce ve deneyimleri yanı sıra kişisel bilgi ve görsellerini, tanıdık ya da yeni arkadaşlarıyla paylaşmalarını sağlayan sosyal medya, yeni ilişkiler geliştirmenin yeni ve en önemli yolu olarak görülmektedir. Çalışmanın genel amacı, üniversite öğrencilerinin sosyal medyada kendini açma düzeylerini ortaya koymak; kendini açma ile özsaygı, algılanan fayda ve kullanıcılara duyulan güven arasındaki ilişkinin izlerini sürmektir. Çalışmada özellikle üniversite öğrencileri gibi toplumun ergen ve genç yetişkinlerinin seçilmesinin nedeni ise; onların sosyal medya erişimlerinin ve bilgi birikimlerinin daha fazla olması, dolayısıyla diğer nüfus gruplarına kıyasla, sosyal medya kullanıcısı olma ihtimallerinin daha yüksek düzeyde bulunmasıdır (Balc1, vd., 2019, s.180).

\section{Sosyal Medyada Kendini Açma}

Teknolojik gelişmeler çerçevesinde gerçek hayatın bir simülasyonu olarak oluşturulan sanal ağlar bireylere yeni alanlar açarak alternatif bir ortam sunmaktadır. Dolayısıyla bu yeni ortamda kendi benliğini istediği gibi ortaya koyabilme rahatlı̆̆ına sahip olan birey farklı şekillerde kendine yer açmaktadır. Zafer Özdemir (2015)'e göre sosyal ağların bu bağlamda önemli özelliklerinden biri kullanıcılara kimlik üretme imkanı sunması yanında yeni kimlikler üretmeye de teşvik etmesidir. Kullanıcıların üyesi olduğu platformlarda gerçekleştirdikleri görüntü, video ve yorum paylaşımları o bireylere özgü düşünce ve deneyimlerden örnekler sunmaktadır. Bu sayede kullanıcılar kendilerine ait resim ve görsellerin bulunduğu alanlar oluşturarak bu sosyal çevrede var olmaya çalışmakta sürekli yeni ve yeniden güncelleme ve paylaşımlarla etkileşime girmeye çalışmaktadır. Birey, sosyal medya üzerinden yaptığ mektir (s.113-121). İnternet öncesi dönemde kullanılan kendini açma davranışlarının sözel olarak ele alınan kısımlarının daha çok benlik üzerine olduğunu belirten Jinsuk Kim ve Kathryn Dindia (2011), çevrimiçi sanal ortamlarda kendini açma davranışının ne şekilde ele alındığını araştırdıkları çalışmalarında, internet odaklı yeni iletişim biçimlerinin bireyler için yeni bir 
kendini ifade etme ortamı olarak ele alınırken; kişisel sunumda görüntünün öneminin daha da belirginleştiği sonucuna varmışlardır.

Bireylerin bir iletişim yöntemi olarak kendini açma davranışını tercih etmeleri tamamen kişisel ihtiyaçlarına ve beklentilerine cevap bulma maksadını içerdiği gibi, duygusal ve bilişsel anlayış beklentileri için de kullanılmaktadır (Posey, et al., 2010, s.183). Bireyin kendi kişisel bilgilerini iletişime geçmek amacıyla karşısındakine ilettiği ve bu sayede etkileşime geçilen bir süreç olarak tanımlanan kendini açma davranışı, ikili ilişkilerin gelişmesinde ve sağlıklı bir şekilde yürütülebilmesinde önemlidir. Ancak kendi içerinde özellikle, hangi zamanlarda, kimlere, hangi şekillerde açlacağı ve nelerin açılanacağı gibi konularda engelleri de barındırabilir (Çetinkaya ve Akbaba, 2011, s.2).

Clay Posey ve arkadaşları (2010, s. 183)'na göre kendini açma belirli boyutlarda gerçekleşmektedir. Buna göre kişisel ifşanın boyutu (1), bir bireyin açıklamalarının sıklığını ve süresini temsil ederken, derinliği (2) iletişimdeki samimiyet derecesini yansıtır. Dürüstlük (3), kişinin kendisiyle ilgili bilgileri ilettiği doğruluk anlamına gelmektedir. Kişisel ifşadaki niyet (4), bireyin kendi beyanları üzerinde kontrol ve farkındalığı yansıtırken, birleşme değeri (5), iletişimde açıklanan bilginin olumlu doğasını ortaya koymaktadır. Bir başka ifadeyle kendini açma genişliği ve derinliği bakımından değişebilir. Genişlik, açıklanan alanların sayısına (örneğin iş, aile, politik yönelim) vurgu yaparken, derinlik yüzeysel-kişisel boyut anlamına gelir (Utz, 2015, s.2).

Sonja Utz (2015)'a göre bilgisayar destekli ortamlarda kendini ifade hareketi, içinde birçok farklı faktörü barındırmaktadır. Bunlardan ilki profil resmi ve kişisel birçok bilginin açıklanmasıdır. Ancak bu ifade eylemi, genellikle tanıdıklarımızı içeren bir ortama yapılmakla birlikte, bilginin mahremiyetinin sağlanamadığı bir ortamda varlığını sürdürmektedir. Utz (2015) yaptığı çalışmada kamusal ve özel iletişim arasındaki sınırların bulanıklaştığı kanısına varırken aynı zamanda sosyal ağlarda kendini samimi, eğlenceli ve pozitif gösterenlerin daha çok beğenildiği, dolayısıyla özsaygısının yükseldiği verisine ulaşmıştır. Başka bir ifadeyle çalışma ifşa, samimiyet, beğenme ve bağlılık hissi arasında açık bir bağlantı bulunduğunu ortaya koymaktadır (s.7-9).

Yukarıda da değinilen bilgilerin ışığında bireylerin iletişim kurabilmeleri için karşılıklı olarak bir şeyler paylaşması, ilişkinin gelişimi için hayati önem taşıdığı söylenebilir. Sosyal ilişkiler geliştirmek için taraflar kendilerini belir- 
li düzeyde açığa vurmak zorundadır. Böylece iletişim kuran her iki taraf da birbirleri hakkında daha sübjektif davranabilir ve ilişkinin yoğunluğunu ayarlayabilir. Dolayısıyla kendini açıklamadaki faktörlerin miktarı ve pozitifliği, iletişim kuracak tarafların kullanıcılara olan izlenimlerini ve güvenini artıracağı ve arkadaşlıklarını ve yakınlıkların daha da güçlendireceği söylenebilir (Yu, 2015, s.3).

Bunun yanında son olarak değinmek gerekirse sosyal hayatta olduğu gibi sosyal medya kullanımlarında da bireysel farklılıklar bulunan kadın erkek ilişkileri kendini açma konusunda da farklılıklar göstermektedir. Cinsiyet farklılıklarının sosyal medya kullanımı ve sosyal medyada kendini açma davranışı üzerinde etkili olduğunu söyleyen Yu ve arkadaşlarının (2017, s.89) yapmış olduğu çalışmaya göre; cinsiyetler arasında internette kendini açıklama derecesine bakıldığında kadınların sosyal ağlarda daha fazla arkadaşa sahip oldukları ve kendilerini göstermek ve ifade etmek için daha aktif oldukları görülmektedir. Yine Christien Marie Seamon (2003, s.161)'un yapmış olduğu araştırmaya göre de kendini açmanın cinsiyet farklılıkları konusundaki literatürle uyumlu olarak, kadın katılımclar erkek katılımcılara oranla kendilerini daha fazlasını açıklamaktadırlar. Kadınların neden erkeklerden daha fazla kendini açma eğiliminde oldukları konusunda bir takım nedenler öne sürülmektedir. Ancak kesin sebepler için derinlemesine bir araştırma yapılabilir.

\section{Özsaygı ve Sosyal Medyada Kendini Açma}

Kendini açma, genel olarak ilişkilerde düşünme ve hissetme aşamasında önem taşıyan, kişiler arası etkileşim sağlayan ana etken olarak ele alınırken (Green, Derlega ve Mathews, 2006, s.411), özsaygı ise kişinin gurur duygu$\mathrm{su}$, olumlu değerlendirme veya kendine saygısı olarak tanımlandığı gibi daha geniş bir güven kavramı olarak da tanımlanabilir (Ingólfsdóttir, 2017, s.2; Al-Ghafri ve Al-Badi, 2016, s.4). Özsaygı açık ve örtük olmak üzere iki şekilde ortaya çıkmaktadır. Literatür genel olarak açık özsaygı üzerine yoğunlaşırken; örtük özsaygı konusu çok fazla çalışılmamaktadır. Açık saygı Morris Rosenberg (1965) ölçeği ile elde edilen veriler üzerinden yorumlanmaktadır, ancak örtük özsaygı için bir dizi deneysel veriye gerek duyulmaktadır (Lima, 2007, s.2). 
Özsaygı tipine bakılmaksızın, bu yapı hakkındaki en yaygın gerçeklerden biri, tüm insanların onu korumak ve/veya yükseltmek için hayati bir gereksinim duymalarıdır. Bu düşünce hattına paralel olarak, bireylerin hem çevrimiçi hem de çevrimdışı sosyal ortamlarda olumlu kişisel sunumlar için çaba göstermeleri beklenmektedir. Özsaygısı düşük olan kişilerin, kendi özgüvenlerini artırabilecek çevrimiçi faaliyetlerde bulunmak için daha fazla istekli olmaları da muhtemeldir (Mehdizadeh, 2010, s.358). Dolayısıyla günümüz sosyal medya etkinliklerinde bireyler, hedef kitlesinin ilgisini çekebileceğini düşündüğü içerikler paylaşmakta, bu araçlar üzerinden paylaştıkları fotoğrafların da -beğenilebilir- olmasına özen göstermektedir. Bu çerçevede sosyal medya, bireylerin fiziksel ve bilişsel varoluşlarını yansıttıkları ama bunu da sosyal medyada beğenilecek şekilde gerçekleştirdikleri sosyalleşme ortamı olarak ele alınmaktadır (Özdemir, 2015, s.114).

Diğer bir ifadeyle sosyal medyanın bireylerin özsaygısı üzerinde çok güçlü bir etkisi vardır. Özellikle genç nesil bu sosyal paylaşım sitelerini bilgi, iletişim, ilişki kurma ve ilişkilerin sürdürülmesi için kullanırlar. Ancak bireylerin büyük çoğunluğu, diğerleriyle kendisi arasında yukarı ve aşağı karşılaştırmalar yapmaktadır. Yukarı doğru yapılan karşılaştırmalar, insanları başkalarını ve yaşam tarzlarını kıskandırırken, ödülleri için daha az sorumlu ve nankör hissettirmektedir. Ancak aşağı doğru karşılaştırmalar yapan kişilerde ise durum daha pozitif ilerlemekte ve özsaygıyı artırmaktadır (Jan, Soomro ve Ahmad, 2017, s.337).

Kendini açma davranışının en önemli belirleyicisinin özsaygı olduğunu söyleyen Seamon (2003, s.164) yapmış olduğu araştırmada; hem özsaygının hem de kendini açmanın çok yönlü olduğuna ve potansiyel olarak birbirlerini çeşitli şekillerde etkileyebildiğine dikkat çekmektedir. Çalışmada kendini açma davranışının cinsiyet farklılıkları, yakınlık derecesi gibi parametreler ışığında değerlendirilmesinin yanında özsaygı ile ilişkisi de ele alınmaktadır. Sonuç olarak araştırmada kendini açma ve özsaygı arasındaki bağlantıda, sayılan başlıkların etkisinin oldukça yüksek olduğu ortaya konmuştur.

Nicole Kashian ve arkadaşları (2017, s.282) bilgisayar destekli uygulamalarla yapılan iletişimin kendini açma ve özsayg üzerindeki etkilerini araştırdıkları çalışmada, bireylerin kendini ifade etme davranışları sırasında sergiledikleri tavırların, etkileşime girdikleri bireylerle iletişimlerinde belirleyici rol oynadığı sonucuna ulaşmıştır. Çalışmada kendini ifade etme sıra- 
sında alıciların veya alıcı ortakların bu durumdan hoşlanmasına yol açan kişisel niteliklerin önemine dikkat çekilerek, özsaygı tutumu ile bağlantısına vurgu yapılmaktadır. Çalışma sonuçları ele alındığında, kişilerarası nitelikler yoluyla kendini açma ve özsaygiyı birbirine bağlayan model desteklenmekte ve sosyal ağlar üzerinde bir açıklama- özsaygı etkisi olduğunu ortaya koymaktadır.

Crystal Jiang, Natalie Bazarova ve Jeffrey Hancock (2011) ise yaptıkları araştırmada yüz yüze iletişime oranla bilgisayar aracılı iletişimde kendini açmanın daha yoğun yaşandığı ve bunun da bireyler arasındaki ilişkilerde belirleyici bir rol oynadığını göstermiştir. Benzer konuya dayalı bir diğer araştırmalarında ise, sosyal ağları üzerinden gerçekleştirilen yüksek düzeyli kendini açma, iletişim kuran her iki bireyin de birbirlerine olan samimiyet duyguların artırırken aynı zamanda özsaygılarını da artırmakta olduğu bulgusuna ulaşılmıştır (Jiang et al., 2013).

Kendini açma davranışının sosyal medya üzerinden gerçekleşmesi, farklı yaş gruplarında elde edilen faydalar ele alındığında, belirli boyutlar çerçevesinde ilerlemekte ve analiz edilmektedir. Shu-Yin Yu (2015) yaptığı çalışmada yaşlı bireylerin sosyal ağ kullanımında kendini açıklama ve özsaygılarını ele alırken aynı zamanda algılanan sosyal destek ile kendini açıklamanın miktarı, derinliği, dürüstlüğü, değerliliği ve niyetini de incelenmiştir. Sonuçlara bakıldığında ise; yaşlı kullanıcılardan sosyal destek ve özsaygısı daha yüksek olanların kendini açıklama davranışlarında derinliğin, dürüstlüğün ve niyetin daha yüksek oranda gerçekleştiği görülmektedir. Ayrıca kişisel açıklamaların yapılmasının, yaşlı kullanıcıların özgüveninin ve özsaygısının önemli bir göstergesi olduğu üzerine vurgu yapılmaktadır. Aynı zamanda sosyal medya kullanımından elde edilen faydalara da değinen Yu (2015), yaşlı kullanıcıların başkalarıyla olan sosyal ilişkilerinde kendini ifade etmeye ne kadar istekli olurlarsa, geliştirecekleri sosyal ilişkilerinde özsaygının o derece artacağına ve ilişki değerinin de yükseleceği konusuna değinmektedir.

Özsaygısı düşük bireyler için sosyal medyanın, özsaygısı yüksek olan bireylere göre, daha önemli görülmesinin birkaç sebebi vardır. Buna göre öncelikle düşük özsaygıya sahip kişiler, sosyal medyada kendileri/oldukları gibi davranmak zorunda kalmadıkları için daha rahat bir iletişim kurarlar. Bir diğer sebep ise; yüz yüze iletişimin ve sonuçta alınacak tepkinin özsaygisı düşük bireylerde büyük bir sorun olarak görülmesi, sosyal medyada 
iletişim kurmanın daha cazip bir yol olduğu düşüncesini pekiştirmektedir (Forest \& Wood, 2012, s.296).

Dana Leighton ve arkadaşlarının (2018) araştırmasında ise özsaygısı düşük olanların sosyal medya üzerinden yüz yüze etkileşimlere kıyasla kendini açılamanın da pozitif algılandığını gösteren bulguları ön plana çıkarmaktadır. Analiz sonucunda Forest ve Wood'un (2012) elde ettiği sonuçların birçoğu desteklenmektedir. Özsaygı, yüz yüze iletişime göre sosyal medya da kendini açma davranışında önemli rol oynarken, kendini ifade etme davranışında algılanan faydalar ön plandadır.

Amanda Forest ve Joanne Wood (2012, s.297-300) ise yaptıkları çalışmalarında, sosyal medyayı, özsaygısı düşük katılımcıların, özsaygıları yüksek olan katılımcılara göre kendilerini ifade etmek için daha güvenilir bir yer olarak gördükleri sonucuna varmışlardır. Araştırmada elde edilen bir diğer sonuç, özsaygının düşük olduğu kişilerin sosyal medya kullanma biçiminin ve potansiyel sosyal faydalarına ulaşmalarını engelleyebileceğini de göstermektedir. Dolayısıyla özsaygısı düşük olan kişilerin sosyal medyayı kendini açma konusunda güvenli, çekici bir yer olarak gördüklerini ve özsaygınlığı yüksek olan insanlar kadar çok zaman harcadıkları görülmektedir.

Bir başka noktada günümüzde, sosyal medya insanların iletişim kurma biçimini önemli şekilde değiştirmiştir. Bu araçlar, bireylere yüz yüze iletişim süreçlerine kıyasla normalde gösteremedikleri durumları ve bazı özelliklerini saklama olanağı gibi alternatifler sunduğu için, ilgi çekici iletişim ortamları olarak öne çıkmaktadır (Sheeks ve Birchmeier, 2006, s.64). İnsanlar çevrimiçi etkileşimlerde olumlu bir görüntü oluşturmak için kendilerini daha dikkatli ve kendi kendine hizmet veren bir şekilde temsil etme eğilimindedir. Sosyal medya aracilığıyla gerçekleşen iletişimin geri bildirimli yapısı, karşılıklı bilgi edinmede önemli bir rol oynadığı gibi, aynı zamanda kişinin kendini tanıtmasını sağlamaktadır. Bu nedenle, çevrimiçi karşılıklı etkileşim, bireylerin kendilerini orijinal doğalarından farklı bir şekilde sunmalarına ve sonuç olarak kendilerini farklı algılamalarına neden olabilmektedir. Karşılıklı etkileşim, bir bireyin kendini ve diğerini algılayışını etkileyebilecek olan bireyin ilişkisel iletişiminin ve çevrimiçi tutumlarının anahtarı olur. Bu noktada bireyin sosyal medyada kendini açıklaması ile özsaygısı arasında bir ilişki bulunmaktadır (Angga ve Walther, 2016). Özsaygısı yüksek ve arkadaş sayısı fazla olan kişiler, sosyal ağlarda daha fazla etkileşimde bulunabilmekte (Yu et al., 2017, s.89) ve kendini ifade edebilmektedir (Seamon, 
2003, s. 155-156). Özsaygısı yüksek olan insanlar kendi yeteneklerine daha fazla güvenirler ve bu nedenle kişisel benliklerini, özsaygısı düşük olan insanlardan daha fazla açıklamaya isteklidirler (Schimel et al., 2001, s.49-50). Kendini açma, sosyal destek ve özsaygı üzerine yapılan bir araştırmanın sonuçları, kendini açma ile sosyal destek ve özsaygı arasında istatistiksel olarak anlamlı ilişkiyi ortaya koymuştur (Yu, 2015). Bu bilgiler ışığında 1 numaralı hipotez kurulmuştur:

- H1. Katılımciların özsaygı düzeyi ile sosyal medyada kendini açma davranışı arasında, pozitif anlamlı ilişki bulunmaktadır.

\section{Sosyal Medyada Algılanan Fayda ve Kendini Açma}

Sosyal medya iletişiminde, kullanıcı kendi sayfası üzerinden fotoğraflarını ve resimlerini başkalarıyla paylaşabilir veya kişisel bilgileriyle ilgili verileri sunabilmektedir (Lee ve Ma, 2012, s.332; Special ve Li-Barber, 2012, s.624). Bilgi, eylem için bir temel oluşturmada önemlidir, ancak elde edilmesi maliyetlidir. Sanal bir topluluğun üyeleri arasındaki sosyal etkileşim bağları, daha geniş bir yelpazedeki bilgi kaynaklarına erişmenin ekonomik bir yolunu sağlar (Chiu et al., 2006, s.1877). Üyeler birbirlerinin profillerini görebilir ve e-postaya benzer mesaj bölümleri gibi çeşitli uygulamalar aracılığıyla karşılıklı olarak iletişim kurabilirler (Hughes et al., 2012, s.561). Bu tür etkileşimler, gençleri veya insanları ergenliğin eşiğinde, arkadaşlık ya da ilişki için gerekli bilgiyi sağlaması açısından cezbeder (Pempek et al., 2009, s.228). Sosyal ağ siteleri, kullanıcıların çok fazla zaman ve çaba harcamaksızın diğer kullanıcılarla yeni ilişki kurmasını ve sürdürmesini sağlayan bir dizi kolaylık özelliği sunmaktadır (Ellison et al., 2006).

Bu tarz çevrimiçi etkileşimler, kişilerin kendilerini sunmaları konusunda cesaretlendirir (Walther et al., 2001). Duvardaki küçük bir yazı, başkalarına kendilerini hatırlatmanın ve ilişkileri canlı tutmaya yardımcı olmanın basit bir yoludur. Ek olarak sosyal medya; yeni arkadaşlıklar arayan insanların, bilinmeyen insanlarla ortak bir zeminde, kendileri hakkında daha fazla bilgi sunmalarını olanaklı hale getirmektedir (Krasnova et al., 2010). Öyle ki; ilişkileri sürdürmenin kolaylığı, kullanıcıları, kişisel bilgilerini sosyal paylaşım sitelerinde paylaşmaya teşvik etmektedir (Cheung, 2015, s. 282-283; Krasnova et al., 2010). Yine çevrimiçi etkileşimler, son derece ilginç/ zevkli bir kaynak olabilir (Nambisan ve Baron, 2007, s. 45; Krasnova et al., 2012, s.129). 
Hui ve arkadaşlarının da (2006) vurguladığı gibi, bir şey kullanıcılara eğlenceli geldiğinde; onları, kişisel bilgilerini daha fazla açığa çıkarma noktasinda cesaretlendirmektedir. Eğlenmenin sosyal medya kullanımını artırması ve kendini ifade etmedeki önemi, Krasnova ve arkadaşlarının (2009) ampirik bulgulariyla da desteklenmektedir.

Öte yandan toplumsal bir varlık olarak insan içinde bulunduğu sosyal çevrede sosyal bağlar kurarak ve içinde bulunduğu iletişim ortamiyla varlığını sürdürmektedir. Bu var olma kaygısı hem fiziki hem de ruhsal gelişimi destekleyerek insanın kendisini ifade etmesine sebepler sağlamaktadır. Bu çerçevede bireylerarası güven duygusunu pekiştiren kendini açma davranışı, ulaşıldığı dereceye bağlı olarak ilişkileri güçlendirme görevini de yerine getirmektedir. Yu ve arkadaşları (2017) yaptıkları çalışma bulgularında uygun bilginin açıklanmasının ruh sağlığının korunması üzerinde olumlu bir etkiye sahip olduğunu göstermektedir. Ayrıca algılanan bu faydanın bireyin özgüveni ve arkadaşlık ilişkileri düzeyinde de artış sağladığı elde edilen bulgulardandir.

Dolayısıyla sonuçlar ele alındığında; kendini açma davranışı sonucunda bireylerin sosyal medyadan algıladıkları fayda üzerine büyük etkiye sahiptir. Kendini açma davranışını sergileyen bireyler yüz yüze iletişime oranla daha rahat ve doğal davranabilirken kendilerine duydukları özgüvende de artış yaşanmaktadır. Farklı ağlarda farklı sosyal gruplara dâhil olabilme olanağı sunan sosyal medya, kendini açma davranışının uygun derecede gerçekleşmesiyle bireyler arası ilişkilerde de algılanan faydayı/doyumu artırmaktadır.

Bir başka noktada sözlü iletişimde önemli odak noktalarından olan ve bireylerarası iletişimin belirleyicisi konumda görülen kendini açma davranışı, bilgisayar destekli sosyal ağlarda da aynı şekilde önemini sürdürmektedir. Çetinkaya ve Akbaba (2011)'ya göre kendini açma davranışı belirli düzeylerde gerçekleşmelidir. Kendini açma fazla ve uygunsuz şekilde gerçekleştirilirse bu bireyin özgüveninde ve düşüncelerinde hasara yol açabilir. Bunun yanında kaliteli, sınırlı kendini açma kişinin özgüvenini ve özsayg1sinı pozitif yönde etkilemektedir.

İşte bu tartışmalarla birlikte 2 numarah hipotez oluşturulmuştur:

- H2. Sosyal medyadan algilanan fayda boyutları ile sosyal medyada kendini açma davranışı arasında, pozitif anlamlı ilişki bulunmaktadır. 


\section{Sosyal Medya Kullanıcısına Güven ve Kendini Açma}

Kendini açma davranışı aynı şekilde devam etse de, bugün yoğunluklu olarak iletişime geçilen ortamların farklılığı beraberinde farklı konuları gündeme taşımaktadır. Birçok kişinin her gün kullandığı sosyal ağlarda kendini açma davranışı, sunulan olanaklar göz önünde bulundurularak çoğunlukla herhangi bir süzgeçten geçirilmeden gerçekleşmektedir. Bu bağlamda sosyal medyanın artan kullanımı, bireylerin gizlilik anlayışını değiştirerek haklarını ve gizliliklerini daha fazla ihlal etmelerine sebep olan davranışlar içine girmelerine neden olmaktadır. Foluke Oduba $(2017$, s.7)'ya göre sosyal medyanın cazip özellikleri göz önünde bulundurulduğunda, pek çok kişi sosyal etkileşimler ve birbirine bağlllık gibi sosyal medyanın kendi kendini bilgilendirme faaliyetlerini daha sık ve yoğun kullanmak için birçok platforma kolayca abone olmaktadır. Dolayısıyla bu medya ortamının özellikleri, insanları çağdaş zamanlarda bilinçli veya bilinçsiz bir şekilde kendi bilgilerini internette dolaşıma açmaya motive etmektedir. Bu sebeple kişisel gizliliğin korunması öncülünde, makul ve uygun bir kişisel açılama, bireye belirli bir sosyal destek sağlamak için, baskıyı hafifletmek, kişilerarası iyi ilişkiler sürdürmek için gerekli görülmektedir (Yu et al., 2017, s.90).

Bir diğer bakış açısına göre her ne kadar günümüzde, kamuya açık konuşma durumlarında kendi kendini açmanın rolüne odaklanan nispeten az sayıda çalışma bulunmasa da, bazıları, kendi kendini açmanın, iletişim ortamını sıcak tutabildiğini ve öğrencilerin konuşma kaygı düzeylerini azaltabileceğini öne sürmektedir (Sellnow ve Golish, 2000, s.50).

Sosyal medya ortamında diğer üyelerin güvenilirliği, kullanıcıların sosyal paylaşım sitelerinde kendilerini açıklamalarını belirleyen önemli bir unsurdur. Sosyal ağ siteleri, kullanıcıların profillerinin, fotoğraflarının ve çevrimiçi etkinliklerinin kolayca bulunabileceği veri bakımından zengin bir ortamdır. Ancak, kullanıcılar çoğu zaman diğer kullanıcıların davranışlarını sosyal ağ siteleri üzerinden izleyemez ve kontrol edemez. Temel olarak, diğer üyelerin açıladıkları kişisel bilgileri kötüye kullanmadıklarına güvenmeleri gerekir. Diğer kullanıcılara duyulan güven, kişisel bilgileri sosyal ağ sitelerinde ifade etme konusundaki gizlilik riskini azaltacaktır (Cheung et al., 2015, s.285).

Söz konusu tartışmalardan yola çıkarak, 3 numarah hipotez ortaya konulmuştur. 
- H3. Katılımcların sosyal ilişkilerde sosyal medya kullanıcılarına güven düzeyi ile sosyal medyada kendini açma davranışı arasında, pozitif anlamlı ilişki bulunmaktadır.

\section{Yöntem}

Yöntem olarak saha araştırmasının kullanıldığı bu araştırmada, Konya Selçuk Üniversitesi Alaeddin Keykubat Kampüsü içerisindeki fakülte, yüksekokul ve meslek yüksekokullarında öğrenim gören öğrencilerden sosyal medya kullanımları, kendini açma, özsaygı ve sosyal medyadan elde ettikleri sosyal fayda üzerine düşüncelerini öğrenmek amaciyla veriler toplanmıştır. Bununla birlikte çalışmada ismi geçen konulara yönelik profili ortaya koymayı amaçlayan betimsel bir yol izlenmektedir.

\section{Araştırmanın Uygulanması ve Örneklem}

Üniversite öğrencilerinin sosyal medyada kendini açma, özsaygı, algıladıkları fayda ve kullanıcılara duydukları güven üzerine odaklanan çalışmada Selçuk Üniversitesi Alaeddin Keykubat Kampüsü içerisindeki fakülte, yüksekokul ve meslek yüksekokulunda öğrenim gören öğrenciler saha araştırmasına dâhil edilmiştir. Örneklemin belirlenmesinde amaçlı örneklem tekniği kullanılırken; araştırmaya konu olan veriler katılımcllarla yüz yüze görüssmeye dayalı anket tekniği ile toplanmıştır. Yapılan incelemenin ardından 395 anketin analize uygun olduğu belirlenmiştir. Seçilen örneklem sayısı, yüzde 5 kesinlik seviyesi ( \pm 0,05 örnekleme hatası) için, araştırma evrenini temsil etme yeteneğine sahiptir (Erdoğan, 2003, s. 440; Yazıcıoğlu ve Erdoğan, 2004, s.50).

Araştırma katılan üniversite öğrencilerinin yüzde 51,4'ü kadın, yüzde 48,1'i ise erkeklerden oluşmaktadır. Çalışmada cinsiyet dağılımı birbirine yakın oranlarda gerçekleştirilerek, araştırmanın güvenilirliğinin sağlanmasina katkıda bulunulmuştur.

Yaş dağılımı betimleyici istatistiklerine bakıldığında; en düşük 18 en yüksek ise 27 yaşındaki katılımcı ile görüşüldüğü ortaya çıkmaktadır. Örneklemdeki bireylerin yaş ortalamasının 20,97; standart sapma değerinin ise 2,51 olduğu görülmektedir. 


\section{Veri Toplama Araçları}

Araştırmada üniversite öğrencilerinin sosyal medyada kendini açma düzeyi ile özsaygı, algılanan fayda boyutları, güven ve kullanım süresi arasındaki ilişkiyi incelemek amacıyla; 5 bölümde, toplam 46 sorudan oluşan bir anket formu hazırlanmıştır. Anket formunda, aşağıda tanımlanan ölçekler kullanılmıştır:

Kendini Açma Ölçeği- KAÖ (Self-Disclosure Scale): Kişilerin kendi durumlarıyla ilgili bilgi, görüş ve duygularını açıklama düzeylerini ortaya koymak amacyyla geliştirilen Kendini Açma Ölçeği, Wheeless ve Grotz (1976) tarafından geliştirilen ve 32 maddeden oluşan bir ölçektir. Wheeless (1978) ile Chen ve Marcus (2012), daha sonra yürüttükleri farklı çalışmalarla ölçekteki madde sayısını yeniden düzenlemişlerdir. Ölçek sadece yüz yüze iletişimde değil, aynı zamanda çevrim içi olarak da bireylerin kendini açma düzeyini test etmek için kullanılabilmektedir (Öksüz vd., 2017, s.587). Ölçeğin Türkçe geçerlilik ve güvenilirlik çalışması, Öksüz ve arkadaşları (2017) tarafından yapılmıştır. Kendini Açma Ölçeğindeki her bir madde için, katılımcılardan oluşturulan bir skala üzerinde, 1-7 arasında (1-Kesinlikle katılmıyorum, 2Katılmiyorum, 3- Orta derecede katılmiyorum, 4-Kararsizım, 5-Orta derecede katılıyorum, 6-Katılyorum, 7-Kesinlikle katılyyorum) puan vermeleri istenmektedir (s. 593). Ölçekten alınabilecek en az puan 16, en yüksek puan 112'dir. Puan arttıkça bireylerin sosyal medyada kendini açma düzeylerinde bir artış yaşanmaktadır. Ölçekte "Niyet, Miktar, Olumluluk, Dürüstlük ve Kontrol" olmak üzere 5 alt boyut bulunmaktadır. Yazarlar KAÖ'nün tümü için Cronbach Alfa katsayısını ,70 olarak tespit etmişlerdir. Bu araştırmada güvenilirlik katsayısı , 69 olarak belirlenmiştir.

Sosyal Medyada Algılanan Fayda Ölçeği: İnsanları sosyal medya kullanımına yönelten nedenler ve bu yönelim sonucunda elde edilecek faydaları sorgulayan ölçek; çeşitli kaynaklardan (Walther et al., 2001; Chiu et al., 2006; Nambisan ve Baron, 2007; Krasnova et al., 2010) yararlanmak suretiyle Cheung ve arkadaşları (2015) tarafindan ortaya konulan 12 maddeden oluşan 7'li Likert tipindedir (1= Hiç Katılmıyorum, 7= Tamamen Katıllyorum). Ölçekten alınabilecek en düşük puan 12, en yüksek puan 84'tür. Sosyal Medyada Algilanan Fayda Ölçeği; İlişkiyi Sürdürme, Yeni İlişki Kurma, 
Kişisel Sunum ve Eğlenme olmak üzere 4 alt boyuttan oluşmaktadır. Bu araştırmada ölçeğin güvenilirlik katsayısı, 88 olarak tespit edilmiştir. Ayrıca İlişkiyi Sürdürme alt boyutu için Cronbach's Alpha değeri ,65; Yeni İlişki Kurma için ,80; Kişisel Sunum için ,79 ve Eğlenme için ,76'dır.

Rosenberg'in Özsaygı Ölçeği (RSES): Morris Rosenberg (1965) tarafından geliştirilen ölçek, bireyin kendi kendine değer verme ve kendini kabul etme hakkındaki genel duygularını değerlendirmek için tasarlanmış olup; 4'lü likert tipi ( $1=$ Kesinlikle Katılmıyorum, 4= Kesinlikle Katılıyorum), 10 maddelik tek boyutlu bir yapıya sahiptir. RSES, beş olumlu (örneğin, “Genel olarak kendimden memnunum") ve beş olumsuz (örneğin, "Kendimde gurur duyacak fazla bir şey bulamıyorum") ifadelerini içermektedir. Negatif ifadeler ters kodlanmış ve daha sonra her katılımcının puanını ortaya çıkarmak için cevaplar toplanmıştır. Yüksek puanlar, özsaygının yüksek olduğunu göstermektedir. Ölçeğin orijinali için iki hafta arayla yapılan test - tekrar test güvenirlik katsayıları ,85 ve ,88 olarak ortaya konulmuştur (Rosenberg, 1979; aktaran; Chubb et al., 1997, s.119). Ölçeğin Türkçeye uyarlaması Çuhadaroğlu (1986) tarafından yapılmıştır. Türkiye'deki diğer araştırmalarda (Bozoğlan vd., 2013; Onaylı ve Erdur-Baker, 2013; Yıldırım \& Demir, 2017) ölçeğin güvenilirlik kat sayısı, 80 olarak elde edilmiştir. Bu araştırmada ise ölçek için Cronbach's Alpha katsayıs1 ,75 olarak tespit edilmiştir.

Sosyal Medya Kullanıcısına Güven Ölçeği: Sosyal ilişkilerde sosyal medya kullanıclarına güven düzeyini tespit etmek üzere; yazarlar tarafından geliştirilen 1 ile 10 arasında puan vermeye uygun bir skaladan yararlanılmıştır. Ölçekten alınabilecek en düşük puan 1 ve en yüksek puan $10^{\prime}$ dur. Ölçek değerlendirmesinde dağılım ; "1-2= Hiç güvenilmez, 3-4= Güvenilmez, 5-6= Orta Düzey ; 7-8= Güvenilir ve 9-10= Oldukça Güvenilir" şeklindedir. Puan arttıkça, sosyal ilişkilerde sosyal medya kullanıcılarına güven düzeyi artış göstermektedir.

Kişisel Bilgi Formu : Bu kısımda yaş ve cinsiyet gibi demografik değişkenlerin yanı sıra, katılımcıların sosyal medya araçları kullanım sıklığı ve süresi ile hangi sosyal medya araçlarını daha çok kullandıklarını sorgulamaya yönelik sorular bulunmaktadır. 


\section{Verilerin Analizi ve Kullanılan Testler}

Saha araştırması 1-15 Ocak 2019 tarihleri arasında, katılımcılarla yüz yüze görüşme yoluyla gerçekleştirilmiştir. Elde edilen veriler, istatistik programı kullanılarak, bilgisayar ortamında analiz edilmiştir. Araştırmada yararlanılan sosyal medyada algilanan fayda (Skewness: -0,267; Kurtosis: -0,148), özsaygı (Skewness: -0,230; Kurtosis: 0,020) ve sosyal ilişkilerde sosyal medyaya güven (Skewness: 0,365; Kurtosis: -0,270) ölçekleri için elde edilen Skewness (Çarpıklık) ve Kurtosis (Basıklık) değerleri -2,0 ile $+2,0$ arasında olduğundan; verilerin normal dağılım gösterdiği dikkat çekmektedir (George \& Mallery, 2010). Bu sonuçlardan yola çkarak, verilerin analizinde parametrik testler tercih edilmiştir. Verilerin analizinde sırasıyla; katılımcıların demografik özelliklerini saptamak amacıyla Frekans Analizi uygulanmıştır. Katılımcıların cinsiyetine göre kendini açma, özsaygı, algılanan fayda boyutları, sosyal medya kullanıcına güven ve kullanım süresi açısından oluşabilecek farklılıkları belirlemek amacıyla Bağımsız Örneklem T-Testi'nden yararlanılmıştır. Sosyal medyada kendini açma alt boyutlarını ortaya koymak için Keşfedici Faktör Analizi tercih edilmiştir. Sosyal medyada kendini açma puanının, özsaygı, algılanan fayda boyutları, güven ve sosyal medya kullanım süresi tarafından nasıl yordandığını tespit etmek amacıyla Doğrusal Regresyon Analizi kullanılmıştır. Yine sosyal medyada kendini açma ile özsaygı, güven ve algılanan fayda arasındaki ilişkinin gücünü ve yönünü ortaya koymak adına Korelasyon Analizi'ne başvurulmuştur.

\section{Bulgular ve Yorum}

Öncelikle araştırmaya katılan bireylerin demografik özellikleri ve devamında sosyal medya kullanım alışkanlıkları, kendini gizleme tutumları ve yaşam doyum analizleri ve yorumları verilmektedir.

\section{Sosyal Medya Kullanım Alışkanlıkları}

Anket çalışmasına katılanların günlük sosyal medya kullanım süresiyle ilgili soruya verdikleri cevapların analizi incelendiğinde; en az 20, en çok 900 dakika sosyal medya kullandıkları bulgusuna ulaşılmıştır. Katılımcıla- 
rın günlük sosyal medya kullanım süresinin ortalaması ise 208,82 dakika olarak belirlenmiştir.

Tablo 1. Sosyal Medya Kullanım Süresinin Betimleyici İstatistikleri

\begin{tabular}{lccccc}
\hline & N & En Az & En Çok & $\bar{X}$ & SD \\
\hline Kullanım Süresi & 379 & 20 & 900 & 208,82 & 137,17 \\
\hline
\end{tabular}

Araştırma sorularına cevap verenlerin cinsiyetine göre günlük sosyal medya kullanım süreleri anlamlı farklılık taşımaktadır $(t=-4,66 ; \mathrm{p}<, 001)$. Betimleyici istatistik sonuçları incelendiğinde; kadınların $(X=240,47)$ erkeklere $(X=176,21)$ oranla günlük sosyal medyayı daha uzun süre kullandıkları da elde edilen veriler arasında yer almaktadır.

Katılımcıların yüzde 74,4'ü her gün düzenli şekilde sosyal medya kullandıkların dile getirirken; yüzde 12,7'si haftada 5-6 gün, yüzde 5,8'i haftada 3-4 gün ve yüzde 5,6'sı haftada 1-2 gün sosyal medya karşısına geçmektedir. Bu bağlamda üniversite öğrencilerinin neredeyse üçte biri, her gün sosyal medya kullanmaktayken; haftada bir iki gün kullanımın oldukça az oranlarda kaldığı dikkat çekmektedir.

Bir başka noktada araştırmaya katılan üniversite öğrencilerinin en çok kullandıkları sosyal medya aracı yüzde 33,7 ile Instagram olurken, YouTube yüzde 32,4 oranıyla ikinci sırada yer almaktadır. Frekans analizi sonuçlarının da gösterdiği gibi WhatsApp yüzde 21 ile üçüncü, Twitter ise yüzde 11,1 oranıyla dördüncü sırada karşımıza çıkmaktadır. Son olarak yüzde 1,1 oranı ile diğer sosyal medya araçları sıralanmaktadır. Sonuçlar değerlendirildiğinde beş yıl öncesine kadar en çok kullanılan sosyal medya ağı olan Facebook'un listeye giremediği ve son zamanlarda popülerliğini artıran Instagram'ın ise ilk sırada yer alarak, en çok kullanılan sosyal medya aracı olduğu göze çarpmaktadır.

\section{Sosyal Medya Kullanicılarına Güven Düzeyi}

Sosyal ilişkilerde sosyal medya kullanıcılarına güven düzeyi ile ilgili soruya; üniversite öğrencilerinin en düşük 1, en yüksek 10 verdikleri görülmektedir. Betimleyici istatistik analizi sonuçlarına göre, katılımcıların sosyal medyaya çok da fazla güvenmedikleri $(X=4,15)$ ortaya çıkmaktadır. 
Tablo 2. Sosyal Medya Kullanıcılarna Güven Düzeyinin Betimleyici İstatistikleri

\begin{tabular}{cccccc}
\hline & $\mathbf{N}$ & En Az & En Çok & $\overline{\boldsymbol{X}}$ & SD \\
\hline Güven Düzeyi & 389 & 1 & 10 & 4,15 & 2,19 \\
\hline
\end{tabular}

Örneklemdeki bireylerin cinsiyetine göre sosyal medya kullanıcilarına güven düzeyleri anlamlı farklılık göstermemektedir $(t=, 359 ; \mathrm{p}>, 05)$. Betimleyici istatistik sonuçları; hem erkeklerin $(X=4,25)$ hem de kadınların $(X=$ $4,04)$ sosyal medya kullanıcılarına güven bakımından birbirlerine yakın değerlere sahip olduklarına işaret etmektedir.

\section{Özsaygı Düzeyi}

Araştırma sorularına cevap veren sosyal medya kullanıcılarının özsaygı ölçeğindeki maddelere verdikleri puanlar toplandığında; en düşük 13, en yüksek 40 puana sahip oldukları ortaya çıkmaktadır. Katılımcıların özsaygı düzeyi ortalaması ise $X=29,33^{\prime}$ tür. Dağılımın standart sapması ise 4,86 olarak tespit edilmiştir. Bu sonuçlar, üniversite öğrencilerinin yükseğe yakın özsaygı puanına sahip olduklarına işaret etmektedir.

Tablo 3. Özsaygı Düzeyinin Betimleyici İstatistikleri

\begin{tabular}{lccccc}
\hline & $\mathbf{N}$ & En Az & En Çok & $\boldsymbol{X}$ & SD \\
\hline Özsayg1 (İndeks) & 393 & 13 & 40 & 29,33 & 4,86 \\
\hline
\end{tabular}

Katılımcların cinsiyetine göre özsaygı düzeyi anlamlı farklılık oluşturmaktadır $(t=-2,19 ; \mathrm{p}<, 05)$. Betimleyici analiz sonuçları; kadınların $(X=29,85)$, erkeklere $(X=28,78)$ göre daha yüksek özsaygı puanına sahip olduğunu göstermektedir.

\section{Algılanan Fayda Düzeyi ve Boyutlan}

Araştırmanın bu bölümünde öncelikle sosyal medyada algılanan fayda ölçeğindeki 12 madde toplanmak suretiyle tek bir değişkene dönüştürülmüş; betimleyici istatistik analizi ile katılımcıların sosyal medyada algılanan fayda düzeyleri ortaya konmuştur. Örneklemdeki üniversite öğrencilerinin ölçekteki maddelere verdikleri puanlar toplandığında; en düşük 12, en yüksek 84 puana sahip oldukları dikkat çekmektedir. Üniversite öğrencilerinin 
algilanan fayda düzeyi ortalaması ise $X=53,91^{\prime}$ dir. Bir başka anlatımla katılımcların sosyal medyadan algılanan fayda düşünceleri, orta düzeydedir.

Tablo 4. Algılanan Fayda Düzeyi ve Boyutlarnın Betimleyici İstatistikleri ve Güvenilirlik Katsayıları

\begin{tabular}{lccccc}
\hline & $\mathbf{N}$ & En Az & En Çok & $\boldsymbol{X}$ & Cronbach's Alpha \\
\hline Eğlenme & 393 & 3 & 21 & 15,03 &, 76 \\
\hline İlişkiyi Sürdürme & 393 & 3 & 21 & 14,58 &, 65 \\
\hline Yeni İliş̧i Kurma & 393 & 3 & 21 & 12,91 &, 80 \\
\hline Kişisel Sunum & 393 & 3 & 21 & 11,97 &, 79 \\
\hline Algılanan Fayda (İndeks) & 393 & 12 & 84 & 53,91 &, 88 \\
\hline
\end{tabular}

Sosyal medyada algılanan fayda boyutlara ayrıldığında, araştırma sorularına cevap verenlerin en çok puan verdikleri boyut, Eğlenme ( $X=$ $15,03)^{\prime}$ dir. İkinci sırada İlişkiyi Sürdürme $(X=14,58)$ boyutu bulunmaktadır. En az puan verilen boyut ise Kişisel Sunum $(X=11,97)$ 'dur. Ayrıca Tablo 4 incelendiğinde, sosyal medyada algılanan fayda boyutlarının güvenilirlik oranlarının, kabul edilebilir düzeyin üzerinde olduğu dikkat çekmektedir.

Cinsiyete göre İlişkiyi Sürdürme ( $t=-3,03 ; p<, 01)$ ve Eğlenme $(t=-2,26 ; p<$ ,05) alt boyutlarına verilen önem anlamlı farklılık göstermektedir. Betimleyici istatistik sonuçları; kadınların, erkeklere göre, ilişkiyi sürme ve eğlenme amaçlı daha çok sosyal medya kullandıklarını ve fayda sağladıklarını göstermektedir.

\section{Sosyal Medyada Kendini Açma}

Araştırma kapsamında sosyal medyada kendini açma ölçeğinde yer alan 16 madde toplanmak suretiyle tek bir değişken haline getirilmiş; betimleyici analiz sonuçlarıyla örneklemdeki öğrencilerinin sosyal medyada kendini açma düzeyleri tespit edilmiştir. Üniversite öğrencilerinin ölçekteki maddelere verdikleri puanlar toplandığında; en düşük 42, en yüksek 100 puan dikkat çekmektedir. Araştırma sorularına cevap verenlerin sosyal medyada kendini açma düzeyi ortalaması ise $X=71,95^{\prime}$ dir. Dağ $11 ı m ı n$ standart sapması ise 9,93 olarak belirlenmiştir.

Tablo 5. Sosyal Medyada Kendini Açma Düzeyinin Betimleyici İstatistikleri

\begin{tabular}{lccccc}
\hline & $\mathbf{N}$ & En Az & En Çok & $\boldsymbol{X}$ & SD \\
\hline Kendini Açma (İndeks) & 393 & 42 & 100 & 71,95 & 9,93 \\
\hline
\end{tabular}


Katılımcların cinsiyeti, sosyal medyada kendini açma düzeyi açısından anlamlı farklılık meydana getirmektedir $(t=-2,78 ; \mathrm{p}<, 01)$. Kadınlar $(X=$ $73,31)$, erkeklere $(X=70,52)$ nazaran sosyal medyada kendi açma eylemi açısından daha yüksek ortalamaya sahiptir.

Tablo 6. Sosyal Medyada Kendini Açma ile Günlük Sosyal Medya Kullanım Süresi Arasındaki İlişki

Kendini Açma (İndeks)

Sosyal Medya Kullanım Süresi , 048

Öte yandan örneklemdeki bireylerin günlük sosyal medya kullanım süresi ile sosyal medya kendini açma düzeyleri arasında anlamlı ilişki tespit edilememiştir ( $r=, 048 ; \mathrm{p}>, 05)$. Diğer bir ifadeyle, katılımclar arasında günlük sosyal medya kullanım süresinin artması ya da azalması bireylerdeki kendini açma davranışını etkilememektedir.

Katılımciların sosyal medyada kendini açma alt boyutlarını belirlemek üzere, ölçekteki 16 maddeye verilen yantllar doğrultusunda faktör analizi uygulanmış; öz değer (eigenvalue) ve yamaç eğrisi grafiği (screeplot) incelemesi neticesinde 4 alt boyutun ele alınabileceği ortaya çıkmıştır.

Tablo 7. Sosyal Medyada Kendini Açma Alt Boyutlarının Özdeğeri, Açıklanan Varyanslarn ve Güvenilirlik Katsayılan

\begin{tabular}{lccc}
\hline Alt Boyutlar & Özdeğer & Açlklanan Varyans (\%) & Cronbach's Alpha $(\boldsymbol{\alpha})$ \\
\hline Niyet ve Dïrüstlük & 3,18 & 22,24 &, 76 \\
\hline Miktar & 1,94 & 13,98 &, 69 \\
\hline Olumluluk & 1,59 & 12,83 &, 60 \\
\hline Kontrol & 1,05 & 10,79 &, 62 \\
\hline KAÖ TOPLAM & & 59,85 &, 69 \\
\hline KMO Measure of SamplingAdequacy: ,825; Barlett's Test of Sphericity: $\mathrm{X}^{2}=803,31 ; \mathrm{p}=, 000$ \\
\hline
\end{tabular}

Faktör gruplarının sınıflandırılma ve değerlendirilmesinde Varimax rotasyonlu tablo dikkate alınmıştır. Faktör analizinde incelenen maddelerin özdeğeri 1'den daha büyük ve minimum yükleme büyüklüğü 0,50 'dir. Faktör analizi uygulanan maddelerin güvenilirlik katsayısı (Cronbach's $\alpha=, 69$ ) kabul edilebilir seviyededir (Bkz., Yıldız \& Uzunsakal, 2018: 19). Analiz sonucunda ortaya konan boyutlar, sosyal medyada kendini açma açısından toplam varyansın yüzde 59,85'ini açıklama kapasitesi sahiptir (bkz. Tablo 
7). Faktör analizde Niyet ve Dürüstlük en önemli kendini açma alt boyutu olarak ön plana çıkarken; bunu Miktar, Olumluluk ve Kontrol izlemektedir.

Yine çalışma kapsamında kullanıcıların, özsaygı, algılanan fayda boyutları, sosyal medyaya güven ve sosyal medya kullanım süresinin, sosyal medyada kendi açma düzeyini belirleme gücü, Doğrusal Regresyon Analizi ile incelenmiş ve elde edilen bulgular Tablo $8^{\prime}$ de gösterilmiştir.

Tablo 8. Sosyal Medyada Kendini Açma Puanının, Özsaygı, Algılanan Fayda Boyutları, Güven ve Sosyal Medya Kullanım Süresi Tarafından Yordanmasına İlişkin Doğrusal Regresyon Analizi Sonuçlarn

\begin{tabular}{lcccc}
\hline & B & Beta $(\beta)$ & $\mathbf{t}$ & \multicolumn{1}{c}{ Sig. } \\
\hline (Sabit) Sosyal Medyada Kendini Açma (İndeks) & 46,715 & & 14,37 &, 000 \\
\hline Özsaygi (İndeks) &, 520 &, 256 & 5,38 &, 000 \\
\hline İlişkiyi Sürdürme &, 531 &, 215 & 3,44 &, 001 \\
\hline Yeni İlişki Kurma &, 438 &, 221 & 3,49 &, 001 \\
\hline Kişisel Sunum &,- 017 &,- 008 &,- 138 &, 890 \\
\hline Eğlenme &,- 196 &,- 080 & $-1,35$ &, 176 \\
\hline Sosyal Medya Kullanıcısına Güven &, 044 &, 010 &, 195 &, 846 \\
\hline Sosyal Medya Kullanım Süresi &,- 002 &,- 025 &,- 499 &, 618 \\
\hline $\mathrm{R}^{2}=, 205 ;$ Adjusted $\mathrm{R}^{2}=, 190$ & \multicolumn{3}{c}{$\mathrm{F}=13,54 ; \mathrm{df}=7 ; \mathrm{p}=, 000$} \\
\hline
\end{tabular}

Özsaygı, algılanan fayda boyutları, sosyal medyaya güven ve sosyal medya kullanım süresinin bağımsız değişken olarak denkleme sokulması sonucu ortaya çıkan modelin anlamlı ilişki gösterdiği dikkat çekmektedir $(\mathrm{F}=13,54 ; \mathrm{p}<, 001)$. Model sosyal medyada kendi açma düzeyini etkileyen değişkenlerle ilgili toplam varyansın yüzde 19'unu açıklamaktadır (Adjusted $R^{2}=$,190). Sosyal medyada kendini açma düzeyini, özsaygı, algılanan fayda boyutları, sosyal medya kullanıcısına güven ve sosyal medya kullanım süresinin yordayıp yordamadığına ilişkin $\beta$ ve $\mathbf{t}$ değerleri incelendiğinde; özsaygı ile $(\beta=, 256 ; \mathrm{p}<, 001)$ ilişkiyi sürdürme $(\beta=, 215 ; \mathrm{p}<, 001)$ ve yeni ilişki kurma $(\beta=, 221 ; p<, 001)$ gibi algılanan fayda boyutlarının, sosyal medyada kendini açma puanını pozitif yönde anlamlı biçimde yordadığı ortaya çıkmaktadır. Bunun yanında kişisel sunum ve eğlenme boyutları ile sosyal medyaya güven ve sosyal medya kullanım süresinin kendini açma düzeyi üzerinde anlamlı belirleyici olmadığı bulgulanmıştır. Krasnova ve arkadaşlarının (2012, s. 132) yaptığı araştırmada eğlenme, hem Alman hem de ABD kullanıcıları için sosyal medyada kendini açmanın belirleyicisi olarak ortaya çıkmaktadır. Yine sosyal medya sağlayıcısı ve üyelerine duyulan güven, 
kendini açma düzeylerini etkilemektedir. Cinsiyetin sosyal medyada kendini açma üzerinde bir etkisi bulunmamaktadır.

Son olarak sosyal medyada kendini açma düzeyi ile özsaygı, sosyal medyadan algılanan fayda düzeyi ve boyutları, güven ve kullanım süresi arasındaki ilişkinin gücü ve yönünü tespit etmek amaciyla Korelasyon Analizine başvurulmuştur.

Tablo 9. Sosyal Medyada Kendini Açma ile Özsaygı, Güven ve Algılanan Fayda Arasındaki İlişki

\begin{tabular}{lc}
\hline & Sosyal Medyada Kendini Açma Düzeyi (İndeks) \\
\hline Özsayg (İndeks) &, $315^{* *}$ \\
\hline Sosyal Medya Kullanıcısına Güven &, 099 \\
\hline İlişkiyi Sürdürme &, $324^{* *}$ \\
\hline Yeniden İlişki Kurma &, $326^{* *}$ \\
\hline Kişisel Sunum &, $192^{* *}$ \\
\hline Eğlenme &, $175^{* *}$ \\
\hline Algilanan Fayda (İndeks) &, $321^{* *}$ \\
\hline
\end{tabular}

Not: ${ }^{* *} p<, 01$

Tablo 9 incelendiğinde, sosyal medya kendini açma ile özsaygı arasında pozitif yönlü zayıf anlamlı ilişki bulunmaktadır $(r=, 315 ; \mathrm{p}<, 01)$. Diğer bir ifadeyle araştırma sorularına cevap veren üniversite öğrencilerinin özsaygı düzeyleri arttıkça, sosyal medyada kendilerini açma düzeylerinde de bir artış yaşanmaktadır. Bu sonuçlar Hipotez 1'in doğrulandığını göstermektedir.

İlişkiyi sürdürme $(r=, 324 ; \mathrm{p}<, 01)$, yeni ilişki kurma $(r=, 326 ; \mathrm{p}<, 01)$, kişisel sunum $(r=, 192 ; \mathrm{p}<, 01)$ ve eğlenme $(r=, 175 ; \mathrm{p}<, 01)$ gibi alt boyutlar ile kendini açma düzeyi arasında pozitif, zayıf düzey anlamlı ilişki, bu araştırma ile ortaya konulmuştur. Bu sonuçlarla Hipotez 2 doğrulanmaktadır. Yine sosyal medyada kendini açma ile algilanan fayda (indeks) arasında pozitif yönlü, zayıf anlamlı ilişki $(r=, 321 ; \mathrm{p}<, 01)$ dikkat çekmektedir. Katılımcların sosyal medyadan algılanan fayda düzeyleri arttıkça, sosyal medyada kendini açma düzeylerinde bir artış görülmektedir. Cheung ve arkadaşlarının (2015, s. 292) yürüttükleri araştırmada da, algılanan faydaların, yani mevcut ilişkilerin sürdürülmesinin uygunluğu, yeni ilişki kurma, kişisel sunum ve eğlenmenin, sosyal paylaşım sitelerinde kendini açiklamada genellikle güçlü ve pozitif etkilere sahip olduğu tespit edilmiştir. Bulgular sosyal paylaşım sitelerinde kendini açıklama davranışını etkilemede algıla- 
nan maliyetlerden daha fazla algılanan faydaların daha büyük etkilerini ortaya koymaktadır.

Bir başka açıdan sosyal medyada kendini açma düzeyi ile sosyal medya kullanıcısına güven arasında anlamlı ilişki tespit edilememiştir $(r=, 099$; p> ,05). Bu sonuçlar, Hipotez 3 'ün reddedildiğine vurgu yapmaktadır.

\section{Tartışma ve Sonuç}

Yeni iletişim teknolojilerinin sunduğu olanaklara her gün bir yenisi eklenirken, günlük hayatta bu olanakların kullanımına ayrılan zaman da gün geçtikçe artmaktadır. Bu bağlamda bir sosyalleşme ortamı sunan sosyal ağlar; bireyin özellikle kendini yeniden sunduğu ve var olma çabasına girdiği önemli uygulamaları içermektedir. Bireylerin ve toplumların ihtiyaçlarına cevap vermeye çalışan bu teknolojiler, sunduğu çözümlerle ihtiyaçların ötesinde bir noktayı hedeflemekte ve kendi perspektifiyle birey ve toplumu ileri götürmektedir. McLuhan'ın belirttiği gibi birey ve toplum ise kendisine fazladan sunulan seçenekler arasından tercihlerde bulunmakta, gündelik yaşantılarının ve dinamiklerinin bir uzamı olmayı başaran teknoloji ürün ve / veya hizmetlerine sarılmaktadır. Zamanla bu dinamikler birey ve toplum tarafından içselleştirilmekte ve bu doğrultuda farklı ihtiyaçlar için farklı istekler doğmaktadır (Dilmen ve Öğüt, 2010, s. 239). Dolayısıyla toplumsal hayatın bir parçası haline gelen sosyal medya, artık günlük yaşamda bireylere yeni ilişkiler, yeni başlangı̧lar gibi eğlenceli sosyal etkileşimler vadetmektedir. Bireyler gerçek hayatta sahip oldukları ya da olmadıkları birçok şeyi sosyal medyanın tanıdığı olanaklar çerçevesinde sergileyerek yeni bir kimlik oluşturdukları simülasyon dünya yaratarak, bu dünyadan algıladıkları faydayı en üst seviyeye çıkarmayı amaçlamaktadırlar.

$\mathrm{Bu}$ amaca uygun olarak çalışmada üniversite öğrencilerinden oluşan bir örneklem üzerinde araştırma yürütülmüştür. Çalışmada katılımcıların sosyal medya kullanım alışkanlıkları, sosyal medyada kendini açma ve özsaygı düzeyleri, sosyal medyada kendini açma ile özsaygı, algılanan fayda ve sosyal medya kullanıcısına duyulan güven arasındaki ilişki mercek altına alınmıştır.

Araştırma sonuçlarına göre katılımcların günlük ortalama sosyal medya kullanım süreleri 3 saate yakındır. Günümüzde sosyal medya ortamlarına mobil teknolojiler aracı̆̆ıyla bağlanmanın kolaylığı böyle bir sonucun orta- 
ya çkmasında etkili olabilmektedir. Üniversite öğrencilerin yüzde 74,4 gibi önemli bir bölümü her gün düzenli sosyal medya kullandığını dile getirmektedir. Instagram, YouTube ve WhatsApp üniversite gençliğinin daha çok kullandığı sosyal medya araçlarıdır. Kadınlar, erkeklere göre günlük sosyal medya ile daha uzun zaman geçirmektedir.

Yine katılımcıların demografik özellikleri göz önüne alındığında; kadınların, erkeklere oranla sosyal medya üzerinden kendini açma davranışını daha yoğun olarak sergiledikleri dikkat çekmektedir. Elde edilen bu sonuç alanda yapılmış diğer çalışmalarla da uygunluk göstermektedir (Seamon, 2003; Yu et al., 2017, Çetinkaya ve Akbaba, 2011). Benzer şekilde kadınlar, erkeklere oranla daha yüksek özsaygı ortalamasına sahiptir.

Araştırma bulguları sosyal ağlarda bireylerin kendini açma (ifşsa etme) düzeylerine ilişkin veriler ortaya koyarken; aynı zamanda Şekil 1'de görüldügü üzere; sosyal medyada kendini açma ile özsaygı, algılanan fayda ve sosyal medya kullanıcısına duyulan güven arasındaki ilişki yönelik değerlendirmeler sunmaktadır. Analiz sonuçları göstermiştir ki; katılımcılarda özsaygı düzeyi arttıkça sosyal medyada kendini açma düzeyi de artmaktadır. Bir diğer amaç ise bu iki konuya ek olarak sosyal medya kullanımında algilanan fayda düzeylerinin ölçülmesi olarak belirlenmiş ve analizler de bu yönde hazırlanmıştır. Bu çerçevede değerlendirildiğinde, araştırmada kendini açma davranışı ile algılanan fayda düzeyi arasında pozitif yönlü anlamlı bir ilişki ortaya çıkmıştır. Yine araştırma ilişkiyi sürdürme, yeni ilişki kurma, kişisel sunum ve eğlenme gibi algılanan fayda alt boyutları ile kendini açma düzeyi arasında pozitif, zayıf düzey anlamlı ilişkinin varlığına işaret etmektedir.

Öte yandan yapılan daha önceki çalışmalar ve burada elde edilen buğular göz önüne alındığında; kendini açma, bilgisayar aracılı iletişimde, yüz yüze iletişim kurmakta zorlanan bireylere, yeni bir ortam sağlamaktadır. Özsaygısı düşük bireyler için belirli boyutlarda gerçekleşen kendini açma davranışı sosyal ağlarla yeni bir bakış açısı kazanmaktadır. Bu sebeple Forest ve Wood (2012, s.296)'un dediği gibi, özgüveninin düşük olduğu insanlar için sosyal ağlarda kendini açma, yüz yüze açıklama riski olmadan diğer bireylerle ilişki kurmanın bir yolu olabilir. Sosyal ilişkiler kurmada ve sürdürebilmede en önemli bileşenlerden olan kendini açma (Kashian, 2017), özsaygı ve güveni düşük bireyler için sosyal medyanın kullanımıyla arttırılabilir (Jiang, et al., 2013). 
Son söz olarak bu çalışma; Türkiye'de sosyal medyada kendini açma ile özsaygı, algılanan fayda ve sosyal medya kullanıcısına duyulan güven arasındaki ilişkinin doğasına ışık tutmaya yönelik az sayıdaki bilimsel girişimlerden birisi konumundadır. Bu noktada ülkenin farklı bölgelerinde farklı örneklemler üzerinde yapılacak yeni araştırmalarla, hem ulusal literatürün zenginleşmesi hem de karşılaştırmaların yapılması sağlanabilir. Çalışma sosyal medyanın günden güne artan önemine ve insanların günlük yaşaminda hem sosyolojik hem de psikolojik birçok konuya etkisine vurgu yapmaktadır. Bu bağlamda çalışma ayrıca, sanal bir dünya simülasyonu sunan ve gerçek dünya ile paralel duyuları harekete geçiren sosyal ağlarla ilgili yapılacak çalışmalara literatür sağlaması bakımından önem taşımaktadır. Yine gelecekteki araştırmalar, sosyal medyada kendini açma ile ilişkili olabilecek diğer kişisel özelliklerini (narsisizm, yalnızlık, benlik sunumu, öznel iyi oluş, yaşam doyumu vb.) inceleyerek, mevcut araştırmada ortaya çıkan bazı eksikliklere ışık tutabilir. 


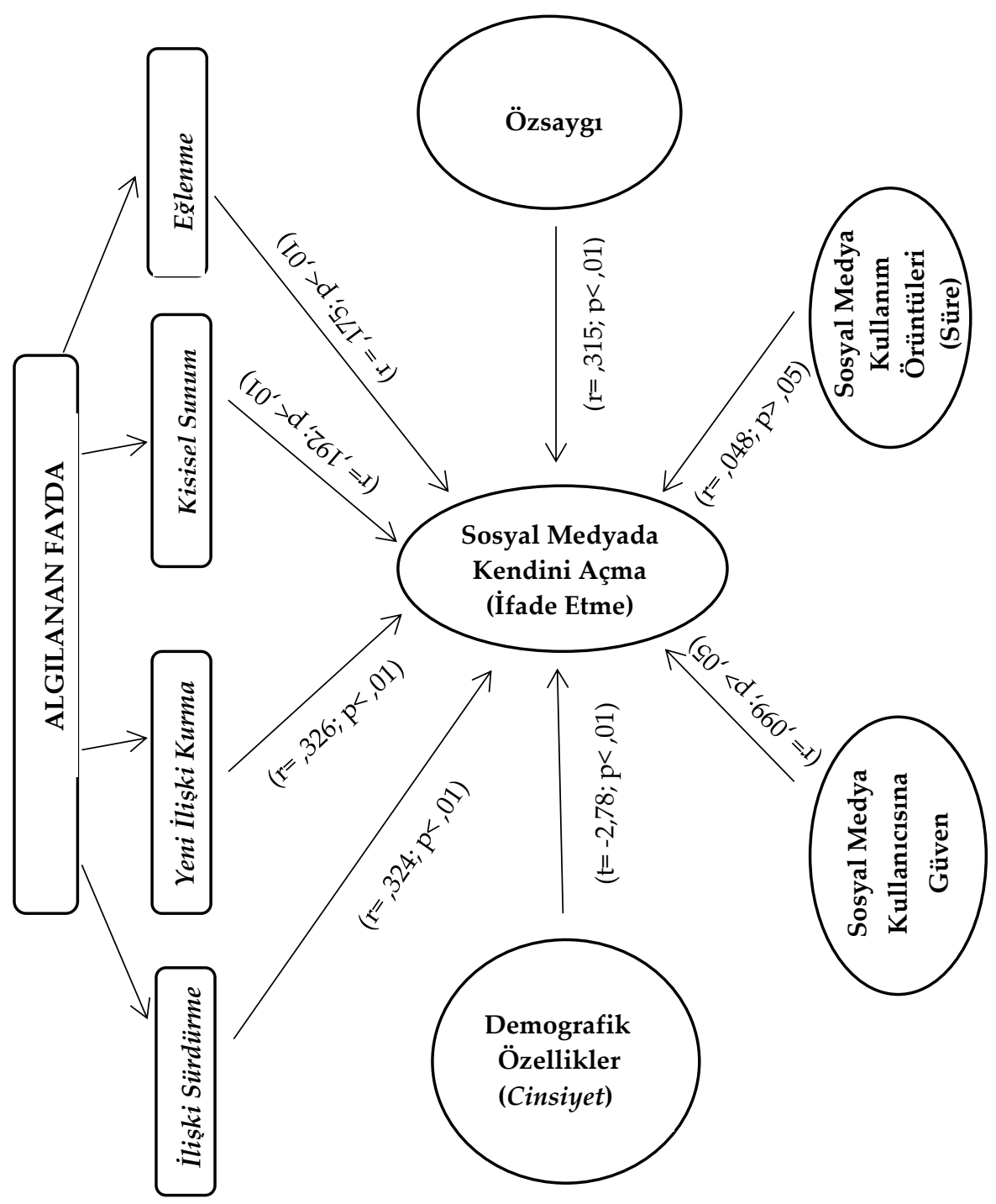

Şekil 1. Sosyal Medyada Kendini Açma ile Özsaygı, Algılanan Fayda ve Sosyal Medya Kullanıcısına Duyulan Güven Arasındaki İlişkiye Yönelik Araştırma Modeli 


\title{
EXTENDED ABSTRACT
}

\section{Self-Disclosure on Social Media: Study on the Effect of Self-Esteem, Trust, and the Perceived Benefits}

\author{
$*$ \\ Şükrü Balcı - Ayşe Arsal Gölcü
Selçuk University
}

While a new one is added to the opportunities offered by new communication technologies every day, the time devoted to the use of these opportunities in daily life is increasing day by day. In this context, social networks that offer an environment of socialization; it includes important practices where the individual re-presents himself and tries to exist. These technologies, which try to meet the needs of individuals and societies, aim at a point beyond the needs with their solutions and take the individual and society forward with their own perspective. As McLuhan pointed out, the individual and the society make choices among the options offered to him, and embrace technology products and / or services that manage to be an extension of their daily lives and dynamics. Over time, these dynamics are internalized by the individual and the society, and accordingly, different demands arise for different needs (Dilmen and Öğüt, 2010, p.239). Therefore, social media, which has become a part of social life, promises fun social interactions such as new relationships and new beginnings to individuals in daily life. Individuals aim to maximize the benefits they perceive from this world by creating a simulation world where they create a new identity by displaying many things that they have or do not have in real life within the framework of social media opportunities.

In the study, the reason why adolescents and young adults such as university students were selected; they have more access to social media and knowledge, so they are more likely to be social media users than other population groups. Data were collected from 395 users using face-to-face survey technique. In accordance with this aim, data were collected from the students of faculties, schools and vocational schools within the Alaeddin Keykubat Campus of Konya Selçuk University. In the analysis of the data; frequency analysis was applied to determine the demographic characteris- 
tics of the participants. Independent Sample T-Test was used to determine the differences in terms of self-esteem, self-esteem, perceived benefit dimensions, trust in social media user and usage period according to gender. Linear Regression Analysis was used to determine how self-esteem score on social media is predicted by self-esteem, perceived benefit dimensions, trust and social media usage time. Correlation Analysis was used to reveal the strength and direction of the relationship between self-esteem and selfesteem, trust and perceived benefit in social media.

As a result of the research, it was found that the average daily social media usage time of the participants was close to 3 hours. 74.4 percent of university students stated that they use social media regularly every day. Instagram, YouTube and WhatsApp are social media tools that university youth use more. Women spend more time with daily social media than men. It is noteworthy that women exhibit more self-disclosure behavior on social media than men. Similarly, women have a higher average self-esteem than men. Analysis results showed that; as self-esteem level increases in participants, self-disclosure level increases in social media. In the study, a significant positive relationship was found between self-disclosure behavior and perceived benefit level. Again, the research points out that there is a positive and weak relationship between perceived benefit sub-dimensions such as maintaining relationship, establishing new relationship, personal presentation and entertainment and self-disclosure level.

In the study, it was determined that perceived benefit dimensions such as maintaining relationship with self-esteem and establishing new relationships positively predicted self-disclosure score in social media. No significant relationship was found between the level of self-disclosure in social media and trust in social media user and duration of social media usage. Considering the previous studies and the mist obtained here; self-opening provides a new environment for individuals who have difficulty in face-toface communication in computer-mediated communication. For individuals with low self-esteem, self-disclosure behavior in certain dimensions can be said to provide a new perspective with social networks. In this study, selfdisclosure in social media Turkey with self-esteem, perceived usefulness and scientific initiatives of the few to shed light on the nature of the relationship between social media users to trust someone is location. At this point, both the enrichment of the national literature and the comparisons can 
be made with new researches on different samples in different regions of the country. The study emphasizes the increasing importance of social media and its impact on many sociological and psychological issues in daily life of people. In this context, the study is also important in terms of providing literature for the studies on social networks that provide a virtual world simulation and stimulate senses parallel to the real world. Again, future studies may shed light on some of the deficiencies in the current study by examining other personal characteristics (narcissism, loneliness, selfpresentation, subjective well-being, life satisfaction, etc.) that may be related to self-disclosure in social media.

\section{Kaynakça / References}

Al-Ghafri, R. K. ve Al-Badi, A. H. (2016). Users' activities on social media as indicators of self-esteem: A case study in Oman, Journal of Internet Social Networking \& Virtual Communities, Article ID: 747714, 1 Nisan 2019 tarihinde https://ibimapublishing.com/articles/IISNVC/2016/747714/747714.pdf adresinden edinilmiştir.

Angga, M., ve Walther, J. B. (2016). The effect of reciprocal self-disclosure attitude on self-esteem in online interactions. Proceedings of the URECA@NTU 2015-16. 1 Nisan 2019 tarihinde file://C:/Users/\%C4\% B0letisim/Downloads/URECA-Mellita\%20(1).pdf adresinden edinilimiştir.

Balcı, Ş., Gölcü, A., ve Gölcü A. A. (2019). Sosyal medya kullanımı ile kendini gizleme ve yaşam doyumu arasında bir bağlantı var mı?. Afyon Kocatepe Üniversitesi Sosyal Bilimler Dergisi, 21(1), 173-190.

Başer, A. (2010). Yeni iletişim teknolojilerinin evriminde televizyonun yeri, F. Aydoğan ve A. Akyüz (Haz.), İkinci medya çă̆ında internet kitabı içinde (s.36-60), İstanbul: Alfa Yayınları.

Bozoğlan, B., Demirer, V., ve Şahin, I. (2013). Loneliness, self-esteem, and life satisfaction as predictors of Internet addiction: A cross-sectional study among Turkish university students. Scandinavian Journal of Psychology, 54(4), 313-319.

Chen, B. ve Marcus, J. (2012). Students' self-presentation on Facebook: An examination of personality and self-construal factors. Computers in Human Behavior, 28, 2091-2099. 
Cheung, C., Lee, Z. W. Y., ve Chan, T. K. H. (2015). Self-disclosure in social networking sites: The role of perceived cost, perceived benefits and social influence. Internet Research, 25(2), 279-299.

Chiu, C. M., Hsu, M. H. ve Wang, E. T. G. (2006). Understanding knowledge sharing in virtual communities: an integration of social capital and social cognitive theories. Decision Support Systems, 42(3), 1872-1888.

Chubb, N. H., Fertman, C. I. ve Ross, J. L. (1997). Adolescent self-esteem and locus of control: A longitudinal study of gender and age differences. Adolescence, 32 (125), 113-129.

Çetinkaya, B., ve Akbaba, S. (2011). Üniversite öğrencilerinin kendini açma davranışları ile bağlanma stilleri arasındaki ilişki. Karadeniz Sosyal Bilimler Dergisi, 3(4), 1-18. $5 \quad$ Mayls 2019 tarihinde https://arastirmax.com/en/system/files/dergiler/195525/makaleler/3/4 Larastirmax-universite-ogrencilerinin-kendini-acma-davranislari-ilebaglanma-stilleri-arasindaki-iliski.pdf adresinden edinilmiştir.

Çuhadaroğlu, F. (1986). Adolesanlarda benlik saygısı. Yayımlanmamış doktora tezi Hacettepe Universitesi Tip Fakuiltesi Psikiyatri Anabilim Dall, Ankara.

Dilmen, N. E., ve Öğüt, S. (2010). Sosyalleşmenin yeni yüzü: Sosyal paylaşım ağları. 2. Yeni İletişim Ortamları ve Etkileşim Uluslararaı Konferansı, 2010, 237-242, 5 Mays 2019 tarihinde http://www.sertacogut.com/blog/wp-content/uploads/2010/05/OgutDilmen-Sosyalle\%C5\%9Fmenin-Yeni-Y\%C3\%BCz\%C3\%BC-SosyalPayla\%C5\%9F\%C4\%B1m-A\%C4\%9Flar\%C4\%B1.pdf adresinden edinilmiştir.

Ellison, N., Heino, R. ve Gibbs, J. (2006). Managing impressions online: selfpresentation processes in the online dating environment. Journal of Computer-Mediated Communication, 11(2), 415-441.

Erdoğan, İ. (2003). Pozitivist metodoloji: Bilimsel araştırma tasarımı. İstatistik Yöntemler, Analiz ve Yorum, Ankara: Erk Yayınları.

Forest, A. L., ve Wood, J. V. (2012). When social networking is not working: Individuals with low self-esteem recognize but do not reap the benefits of self-disclosure on Facebook, Pyschological Science, 23(3), 295-302.

Green, K., Derlega, V. ve Mathews, A. (2006). Self-disclosure in personal relationships. The Cambridge Handbook of Personal Relationship içinde (s.409-427), 1 Nisan 2019 tarihinde https://www.researchgate.net/publication/283409464 Selfdisclosure in personal relationships adresinden edinilmiştir. 
Hughes, D. J., Rowe, M., Batey, M. ve Lee, A. (2012). A tale of two sites: Twitter vs. Facebook and the personality predictors of social media usage. Computers in Human Behavior, 28, 561-569.

Hui, K. L., Tan, B. C. Y. ve Goh, C. Y. (2006). Online information disclosure: Motivators and measurements. ACM Transactions on Internet Technolo$g y, 6(4), 415-441$.

Ingólfsdóttir, H. R. (2017). The relationship between social media use and selfesteem: Gender difference and the effects of parental support. BSc in Psychology, 1-25, 5 Mayı $2019 \quad$ tarihinde https://pdfs.semanticscholar.org/f5d2/30d2f503630e4fb0ef5176da654 94d9c0a4d.pdf? ga=2.6622395.86614734.1587813979$\underline{1603408033.1587813979}$ adresinden edinilmiştir.

Jan, M., Soomro S. A. ve Ahmad, N. (2017). Impact of social media on selfesteem, European Scientific Journal, 13(23), 329-341

Jiang, L. C., Bazarova, N. N. ve Hancock, J. T. (2013). From Perception to Behavior Disclosure Reciprocity and the Intensification of Intimacy in ComputerMediated Communication, Communication Research, 40(1) 125-143.

Jiang, L. C., Bazarova, N. N., ve Hancock, J. T. (2011). The disclosure-intimacy link in computer-mediated communication: An attributional extension of the hyperpersonal model, Human Communication Research, 37, 58-77.

Kashian, N., et al. (2017). Self-disclosure and liking in computer-mediated communication, Computers in Human Behaviour, 71, 275-283.

Kim, J., ve Dindia, K. (2011). Online self-disclosure: A review of research. K. B. Wright \& L. M. Webb (Ed.) Computer Mediated Communication in Personal Relationships içinde(s. 156-180), New York: Peter Lang Publishing.

Krasnova, H., Kolesnikova, E. ve Günther, O. (2009). It won't happen to me!: Selfdisclosure in online social networks, Proceedings of the Fifteenth Americas Conference on Information Systems, San Francisco, California, 1-9.

Krasnova, H., Spiekermann, S., Koroleva, K. ve Hildebrand, T. (2010). Online social networks: Why we disclose. Journal of Information Technology, 25(2), 109-125.

Krasnova, H., Veltri, N. F. ve Günther, O. (2012). Self-disclosure and privacy calculus on social networking sites: the role of culture: Intercultural dynamics of privacy calculus. Business \& Information Systems Engineering, 3, 127-135. 
Kuşay, Y. (2010). Sosyal medyanın gücü ve uygulama örnekleri, F. Aydoğan ve A. Akyüz (Haz.), İkinci medya çă̆ında internet içinde (s.61- 89), İstanbul: Alfa Yayınları.

Lee, C. S., ve Ma, L. (2012). News sharing in social media: The effect of gratifications and prior experience. Computers in Human Behavior, 28, 331-339.

Leighton, D. C., et al. (2018). Self-esteem, self-disclosure, self-expression, and connection on Facebook: A collaborative replication meta-analysis, The International Honor Society in Psychology, Special Issue, 23(2), 98-109.

Lima, E. N. (2007). The association between narcissism and implicit self-esteem: A test of the fragile self-esteem hypothesis. electronic theses, Unpublished Doctoral Dissertation, The Florida State University.

Mehdizadeh, S. (2010). Self-presentation 2.0: narcissism and self-esteem on Facebook, Cyberpsychology, Behavior, and Social Networking, 13(4), 357-364.

Nambisan, S., ve Baron, R. A. (2007). Interactions in virtual customer environments: implications for product support and customer relationship management. Journal of Interactive Marketing, 21(2), 42-62.

Oduba, F. A. (2017). Self-disclosure and motivation in social media use among nigerian women. Unpublished Doctoral Dissertation, Texas A\&M University.

Onayll, S., ve Erdur-Baker, O. (2013). Mother-daughter relationship and daughter's self-esteem". Procedia-Social and Behavioral Sciences, 84, 327-331.

Öksüz, E., Mersin, S., ve Türker, T. (2017). Kendini açma ölçeğinin üniversite öğrencilerinde Türkçe geçerlilik ve güvenilirlik çalışması. Anadolu Psikiyatri Dergisi, 18(6), 586-593.

Özdemir, Z. (2015). Sosyal medyada kimlik inşasında yeni akım: Özçekim kullanımı. Maltepe Üniversitesi İletişim Fakültesi Dergisi, 2(1), 112-131.

Pempek, T. A., Yermolayeva, Y. A., ve Calvert, S. L. (2009). College students' social networking experiences on Facebook. Journal of Applied Developmental Psychology, 30, 227-238.

Posey, C., et al. (2010). Proposing the online community self-disclosure model: The case of working professionals in France and the U.K. who use online communities, European Journal of Information Systems, 19, 181-195.

Rosenberg, M. (1965). Society and the adolescent self-image. Princeton, NJ: Princeton University Press.

Schimel, J., Arndt, J., Pyszczynski, T., ve Greenberg, J. (2001). Being accepted for who we are: Evidence that social validation of the intrinsic self reduces general defensiveness. Journal of Personality and Social Psychology, 80(1), 35-52. 
Seamon, C. M. (2003). Self-esteem, sex differences, and self-disclosure: A study of the closeness of relationships. The Osprey Journal of Ideas and Inquiry, 99, 153-167.

Sellnow, D. D., ve Golish, T. (2000). The relationship between a required selfdisclosure speech and public speaking anxiety: Considering gender equity, Basic Communication Course Annual, 12(6), 28-59.

Sheeks, M. S., ve Birchmeier Z. P. (2007). Shyness, sociability, and the use of computer-mediated communication in relationship development. $C y$ berPsychology \& Behavior, 10(1), 64-70.

Special, W. P., ve Li-Barber, K. T. (2012). Self-disclosure and student satisfaction with Facebook. Computers in Human Behavior, 28, 624-630.

Toprak, A. vd. (2009). Toplumsal paylaşım ă̆ı Facebook: “Görülüyorum Öyleyse Varım!". İstanbul: Kalkedon Yayınları.

Utz, S. (2015). The function of self-disclosure on social network sites: Not only intimate, but also positive and entertaining self-disclosures increase the feeling of connection. Computers in Human Behavior, 45, 1-10.

Walther, J. B., Slovacek, C. L., ve Tidwell, L. C. (2001). Is a picture worth a thousand words? Photographic images in long-term and short-term computer-mediated communication. Communication Research, 28(1), 105-134.

Wheeless, L. R., ve Grotz, J. (1976). Conceptualization and measurement of reported self-disclosure. Human Communication Research, 2, 338-346.

Wheeless, L. R. (1978). A follow-up study of the relationships among trust, disclosure, and interpersonal solidarity.Human Communication Research,4,143-157.

Yazıcıoğlu, Y. ve Erdoğan, S. (2004).SPSS uygulamal bilimsel araştırma yöntemleri. Ankara: Detay Yayıncilık.

Yıldırım, F. B. ve Demir, A.(2017).Kendini engellemenin yordayıcıları olarak özsaygı, öz anlayış ve akademik özyeterlilik.Ege Ĕ̆itim Dergisi,2(18),676-701.

Yıldız, D., ve Uzunsakal, E. (2018). Alan araştırmalarında güvenilirlik testlerinin karşılaştırılması ve tarımsal veriler üzerine bir uygulama. Uygulamalı Sosyal Bilimler Dergisi, 1, 14-27.

Yu, S. Y. (2015). The relationship between social support and self-esteem to the self-disclosure of social media on older adults, The Asian Conference on Media \& Mass Communication 2015: Official Conference Proceedings, November 12-15, Kobe, Japan. 5 Mays 2019 tarihinde http://25qt511nswfi49iayd31ch80-wpengine.netdna-ssl.com/wpcontent/uploads/papers/mediasia2015/MediAsia201519361_.pdf adresinden edinilmiştir. 
Yu, Z., Pengsong, L., Mao, Y., Houwen, C., Ge, S., Zhennan, Z., Zhinan, Z., ve $\mathrm{Na}$, L. (2017). The relationship among college students' internet selfdisclosure, self-esteem and mental health. Humanities and Social Sciences, $5(2), 84-90$.

\section{Kaynakça Bilgisi / Citation Information}

Balcl, Ş. ve Arsal Gölcü, A. (2020). Sosyal medyada kendini açma: öz saygı, güven ve algılanan faydanın etkinliği üzerine bir inceleme OPUS-Uluslararası Toplum Araştırmaları Dergisi, 16(27), 116-149. DOI: 10.26466/opus.669190 